\title{
İbrahim Örs'ün Çocuklara Yönelik Eserlerinin Eğitsel İletiler Açısından İncelenmesi ${ }^{1}$
}

DOI: 10.26466/opus.702195

*

\author{
Serdar Derman ${ }^{*}-$ Murat Acele $^{* *}$ \\ *Dr. Öğretim Üyesi, Necmettin Erbakan Üni. Ahmet Keleşoğlu Eğitim Fakültesi, Konya/Türkiye \\ E-Posta: serdarderman@gmail.com \\ ORCID: 0000-0001-6209-0249 \\ **Doktora Öğr., Necmettin Erbakan Üniversitesi, Eğitim Bilimleri Enstitüsü Konya/Türkiye \\ E-Posta: murat.acele9@gmail.com \\ ORCID: $\underline{0000-0003-4760-5456}$
}

\section{Öz}

Her kitabın okuyucuya vermek istediği bir ileti vardır. Çocukların bilişsel, duyuşsal, ahlaki ve kişilik gelişimlerinde okudukları kitaplardan aldıkları iletiler etkili olmaktadır. Bu sebeple çocuk kitapları, içinde barındırdığı iletiler açısından önem arz etmektedir. Çocuklara yönelik olarak kaleme aldığı eserlerle döneminin güçlü yazarlarından biri olarak kabul edilen İbrahim Örs'ün eserleri Millî Eğitim Bakanlığınca hazırlanan 100 Temel Eser kapsamında öğrencilerimize tavsiye edilmiştir. Bu çalışma, İbrahim Örs'ün çocuklara yönelik yazdı̆̆g 13 eserinde yer alan eğitsel iletilerin tespit edilip incelenerek yazarın eserlerinde çocuklara aktarmak istediği iletilerle çocukların hangi yönlerini geliştirmeyi amaçladığının ortaya çıkarılması amacıyla yapılmıştır. Bu amaçla yazarın eserleri nitel araştırma yöntemlerinden doküman incelemesi yöntemiyle taranmış, eserlerde yer alan iletiler amaçlarına göre sınıflandırılmıştır. İletiler amaçlarına göre 1-Kişisel Gelişimi Destekleyen Ĕ̆itsel İletiler, 2-Toplumsal Gelişimi Destekleyen Ĕ̆itsel İletiler, 3-Ulusal Düşüncenin Gelişimini Destekleyen Ĕ̆itsel İletiler, 4-Çevre Bilinci Gelişimini Destekleyen Eğitsel İletiler, 5-Evrensel Düşüncenin Gelişimini Destekleyen Eğitsel İletiler şeklinde sınıflandırılmıştır. Araştırmanın sonunda İbrahim Örs'ün 13 eserinde 776 farklı ileti tespit edilmiştir. Bu iletilerden en çok 394 ileti sayısı ile "Kişisel Gelişimi Destekleyen" iletilere yer verildiği sonucuna ulaşılmıştır.

Anahtar Kelimeler: İbrahim Örs, Eğitsel ileti, Çocuk edebiyatı, Çocuk yazın

\footnotetext{
${ }^{1}$ Bu makale Necmettin Erbakan Üniversitesi Eğitim Bilimleri Enstitüsünde. 1.yazarın danışmanlığında 2. yazar tarafından hazırlanan “ibrahim Örs'ün Çocuklara Yönelik Eserlerinin Eğitsel Illetiler Açısından İncelenmesi"başıklı yüksek lisans tezinden üretilmiştir.
} 


\title{
Analysis of The Works of İbrahim Örs About Children in Terms of Educational Messages
}

\begin{abstract}
Every book has an intended message to communicate with the audience. Messages of the books impact children's cognitive, affective, moral and personal development. That is why children's books are important in terms of the messages they bear. The works of Ibrahim Örs, who is regarded as one of the strong authors of his period with his works for children, have been recommended to our students within the scope of 100 basic Works prepared by the Ministry of National Education. The aim of this study is to analyze the educational messages of the 13 works of Ibrahim Örs about children to understand what aspect of children he wants to develop in his products. With this aim in mind, document analysis method was used when analyzing his works and the messages were classified in terms of their aims. With regards to their aims, there messages can be classified as follows: 1-Educational Messages that foster personal development 2- Educational Messages that foster societal development 3-Educational Messages that foster nationalistic ideas 4- Educational Messages that foster Environmental Awareness 5- Educational Messages that foster Universal Ideas. The study revealed 776 different messages of Ibrahim Örs in 13 of his works. It is found out that 394 of the messages are related to personal development.
\end{abstract}

Keywords: İbrahim Örs, Educational message, Literature for children 


\section{Giriş}

Bireylerin akademik ve insani yönden gelişmesinde kitapların önemli bir katkısı vardır. Özellikle kişilik gelişiminin büyük çoğunluğunun oluştuğu çocukluk ve ergenlik döneminde okunan ve bu dönem okurlarına yönelik olan kitaplar, içeriği ve okurlarına aktarmak istediği iletiler açısından önem arz etmektedir. Çünkü yazarın eseri aracılığıyla okuruna vermek istediği iletiler, kazandırmak istediği tutum ve davranışlar bireyin akademik, insani, sosyal ve kültürel yönlerden gelişimini etkileyebilir. Bu yönlerden donanımlı hale gelmiş birey, içinde yaşadığı toplumla uyumlu hale gelecek ve toplumsal gelişime de katkı sağlayacaktır.

İnsanoğlu yaratıldığı günden bu yana duygu ve düşüncelerini, başka kişilere aktarmak istemiştir. "Duygu, düşünce veya bilgilerin akla gelebilecek her türlü yolla başkalarına aktarılması, bildirişim, haberleşme, komünikasyon." (TDK Sözlükleri. http://sozluk.gov.tr/, Erişim Tarih:08.06.2019) olarak tanımlanan iletişim, duygu, düşünce ve bilgilerin aktarımıdır.

İletişimin bir ögesi de iletidir. İletişimde, göndericinin alıcıya kanalaracılığıyla gönderdiği kod olan ve TDK Güncel Sözlük"te "Yazı veya sözle verilen, gönderilen bilgi, mesaj" olarak tanımlanan ileti hakkında bazı araştırmacıların görüşleri şöyledir:

İletiyi “ Her yazı ya da yaratı bir ileti (mesaj) taşır. Bu bir yönüyle yazarınkonuya yüklediği anlamdır. Yazarı yazmaya iten etkendir. Başka bir deyişleokuyucusuna vermek istediği ana düşünce, ana duygudur." (Özdemir,2007, s.23-24 ) şeklinde tanımlayan Özdemir'e göre ileti ana düşüncedir.

Aytaş ve Yalçın (2003, s.45)'a göre "Her edebi eser, muhataplarına bir mesajverir. Sanatçı duygu ve düşüncelerin paylaşmak üzere onu kendisine has ifadebiçimiyle ortaya koyar. Bu ortaya koyuş çeşitli şekillerde olabilir. (...) işte yazılı ve sözlü eserlerde iletilmek istenen temel duygu ve düşünceye ana fikir denir."Sever (2017, s.140) iletiyi şu ifadelerle açılamaktadır: "İleti (ana düşünce),yazarın okurla paylaşmak istediği asıl düşüncedir. Öğretici metinlerde, yazarın savunduğu, vermek istediği düşünce biçiminde de tanımlanabilir. Edebiyat yapıtlarında ileti dendiğinde ise, sanatçının okurlarında yaratmak ve oluşturmakistediği duygu ve düşünce ortaklığı akla gelmelidir."Özdemir (2007, s.24)'e göre " iletisi olmayan bir şiir, bir roman, bir öykü ya daanlatı düşünülemez." 
Çocuk kitapları, okurlarına vermek istedikleri iletilerle onların hayaldünyalarını zenginleştirmeli, yaratıcı düşünme, problem çözme gibi bilişselbecerilerinin yanında onları davranışsal boyutta da iyiye ve olumluya yönlendirmeli, onların ahlakî ve kişilik gelişimine de katkı sağlamalıdır.

İletilerin taşıması gereken özellikleri Demirel ve diğerleri şu şekilde ifade etmişlerdir:

- "Illetiler çocuğun bilişsel, duyuşsal gelişim özelliklerine uygun olmalı,

- çocuğun söz konusu gelişim boyutlarına olumlu katkılarda bulunmalıdir.

- İletiler ile konu-tema arasında yakın bir ilişkinin olmasına dikkatedilmeli.

- İletilerin aktarımında önemli bir araç olan konu, dil ve anlatım gibiözellikler, kendi içlerinde bir uyumu barındırmalıdır.

- İletilerin aktarımında anlatılan metnin özelliği de dikkate alınarak, eldengeldiğince zengin bir yola başvurmalıdır. Yani sadece örtük iletiler

- şeklinde değil, yerine göre doğrudan, dolaylı ve soru şeklindeki iletilerinde metnin içine yedirmiş olmalıdır.

- İletiler tıpkı tema/ ana fikir gibi eserin yazılma nedeni hâline gelebileceği için en az tema/ ana fikir kadar üzerinde ciddi bir biçimde durulmalıdır"(2011, s.58-59).

Gazeteci kimliği ile bilinen İbrahim Örs aynı zamanda 1970-1985 yılları arasında çocuklara yönelik 10 eser yazmıştır. Yazarın "Göl Çocukları" adlı eseri Millî Eğitim Bakanlığı tarafından 2005 yılında yayınlanan “İlköğretim Okullarında Okutulacak 100 Temel Eser" adlı listede yer almıştır.

Bu açıklamalar doğrultusunda bu çalışmanın amacı İbrahim Örs'ün çocuklara yönelik olarak yazdığı 13 eserde yer alan eğitsel iletilerin tespiti ve bu iletilerin amaçlarının bulunması olarak belirlenmiştir. Bu amaçlar doğrultusunda aşağıda yer alan problem ve alt problem cümlelerine yanıt aranmıştır.

\section{Problem Cümlesi}

İbrahim Örs'ün çocuklara yönelik eserlerinde yer alan eğitsel iletiler nelerdir ? 


\section{Alt Problemler}

1. İbrahim Örs'ün eserlerinde yer alan kişisel gelişimi destekleyen eğitsel iletiler nelerdir?

2. İbrahim Örs'ün eserlerinde yer alan toplumsal gelişimi destekleyen iletiler nelerdir?

3. İbrahim Örs'ün eserlerinde yer alan çevre bilinci gelişimini destekleyen eğitsel iletiler nelerdir?

4. İbrahim Örs'ün eserlerinde yer alan ulusal bilincin gelişimini destekleyen eğitsel iletiler nelerdir?

5. İbrahim Örs'ün eserlerinde yer alan evrensel düşüncenin gelişimini destekleyen eğitsel iletiler nelerdir?

\section{Araştırmanın Amacı}

Bu araştırmanın amacı İbrahim Örs'ün 13 eserinde bulunan eğitsel iletileri tespit etmek, bunların amaçlarını ortaya çıkarmaktır.

\section{Araştırmanın Önemi}

Eğitimin vazgeçilmez araçlarından biri olan kitabın içeriği önemlidir. Ders için ya da edebi amaçla hazırlanmış bir kitap, okurunda meydana getirmek istediği bilgi, duygu ve davranış değişiklikleri açısından çocuğun seviyesine uygun içerikler barındırmalıdır. Çocuklara yönelik yazınsal türlerin nitelikleri onların bilişsel, duyuşsal, ahlaki ve insani yönden geliştirmesi açısından önem arz etmektedir.

İbrahim Örs'ün eserlerinde yer alan iletilerin ve bu iletilerin amaçlarının tespitinin yazınsal türler üzerine yapılacak çalışmalara yardımcı olacağı düşünülmektedir.Aynı zamanda tespitler, eğitimcilere ve anne babalara, çocukların ihtiyaçlarına yönelik okuma tavsiyeleri için yol gösterecektir.

\section{Sinırlılıklar}

Bu çalışmanın kapsamını İbrahim Örs'ün çocuklara yönelik olarak yazdığı 13 eseri oluşturmaktadır. "Göl Çocukları" adlı eser daha önce “Cambazlar 
Kralı" adıyla yayımlandığı için içeriği aynı olması sebebiyle "Cambazlar Kralı" adıyla yapılan yayımı kapsam dışı tutulmuştur.

\section{Yöntem}

İbrahim Örs'ün çocuk edebiyatına yönelik eserlerinde yer alan eğitsel iletileri ortaya çıkarmak amacıyla hazırlanan bu çalışma nitel esaslı betimsel bir çalışmadır. Bu tür çalışmalarda veriler araştırma sorularının ortaya koyduğu temalara göre düzenlenebilir(Yıldırım ve Şimşek, 2011, s.224). Bu çalışmada İbrahim Örs'ün çocuklara yönelik olarak yazdığı eserlerinde yer alan eğitsel iletilere odaklanılarak beş farklı kategori ve bu kategorilere ait kodlar oluşturuldu.

\section{Araştırmanın İnceleme Nesneleri}

Araştırmanın inceleme nesneleri çalışmaya konu olan İbrahim Örs'ün eserlerinden oluşmaktadır. Yazarın 13 eseri Karacan, Milliyet, Şimşek, Nemesis Yayınevleri tarafından basılmıştır. Yazarın güncel yayını olmayan bazı kitapları Millî Kütüphaneden temin edilmiştir. Yazarın daha önce "Cambazlar Kralı" olarak yayınlanmış eserine Bolu İl Halk Kütüphanesinde ve İstanbul İl Halk Kütüphanesinde ulaşılmış. İki kitaptan elde edilen verilerin ışığında yazarın "Göl Çocukları" adlı eserini daha önce bu adla yayınladığı sonucuna ulaşılmiştır. Araştırmada inceleme nesneleri olarak kullanılan eserler ve yayınevleri aşağıda belirtilmiştir. Yazarın araştırmamıza konu olan eserleri ve yayınevleri Tablo 1'de listelenmiştir

Tablo 1'de listelenen eserler incelendiğinde yazarın 12 eserinin roman türünde yayımlandığı, yazarın farklı gazete ve mecmualarda yayımlanmış öykülerinin ise 2018 yılında ilgili yayınevi tarafından bir araya toplanarak "Bütün Öyküleri" adıyla yayımlandığı görülmektedir. 
Tablo 1. Araştırmanın İnceleme Nesnelerini Oluşturan Eserler Ve Yayınevleri

\begin{tabular}{lll}
\hline & Kitap adı & Yayınevi \\
\hline 1 & Muhtarın Yeğenleri (1972) & Karacan Yayınları \\
2 & Onur Çocuğu (1974) & Karacan Yayınları \\
3 & Göl Çocukları (Cambazlar Kralı-1975) & Remzi Kitabevi \\
4 & Almanya Öyküsü(1975) & Karacan Yayınları \\
5 & Mücahitin Oğlu (1975) & Milliyet Yayınları \\
6 & Balıklıkoy (1978) & Şimşek Yayınları \\
7 & Çocuk Cumhuriyeti (1980) & Milliyet Yayınları \\
8 & Büyük Tutku (1982) & Karacan Yayınları \\
9 & Yeşil Mağara (1982) & Milliyet Yayınları \\
10 & Fındık Zamanı (1985) & Şimşek Yayınları \\
11 & Atıl'ın Maceraları-1/Sınıftaki Afacan (2018) & Nemesis Kitap \\
12 & Atıl'ın Maceraları-2/Mavi Bisiklet (2018) & Nemesis Kitap \\
13 & Bütün Öyküleri (2018) & Nemesis Kitap \\
\hline
\end{tabular}

\section{Verilerin Toplanmasi}

Araştırmada kullanılacak olan inceleme nesnelerine göre Tablo 1 de verilen eserlere ilgili yayınevlerinden, güncel basımı olmayanlara ise Millî Kütüphane, İl Halk Kütüphaneleri katalogları taranarak ulaşıldı. İncelemeye konu olan eserlerin dokümanların aynısı olup özgün hallerinin korunmasına özen gösterildi. İbrahim Örs'ün on üç kitabı bu araştırmanın dokümanlarını/veri kaynağını oluşturdu. Veriler bu dokümanlardan doküman incelemesi yoluyla elde edildi.

\section{Verilerin Analizi}

Çalışma için içerik taraması yapılması gerektiğinden doküman incelemesi yöntemi kullanılmıştır. Yıldırım ve Şimşek'e göre doküman incelemesi, araştırılması hedeflenen olgu veya olgular hakkında bilgi içeren yazılı materyallerin analizini kapsar (Yıldırım ve Şimşek, 2013, s.217).

İbrahim Örs'ün eserlerinde yer alan eğitsel ifadeleri ortaya çıkarmak amacıyla yapılan bu çalışmada, dokümanlar betimsel içerik analizi tekniğiyle (Berg ve Lune, 2015) analiz edildi. Kalıpları, temaları, önyargıları ve anlamları tespit etmek amacıyla belirli bir materyalin dikkatlice, ayrıntılı ve sistematik olarak incelenmesi ve yorumlanmasına içerik analizi denilir. İçerik analizinde kodlamayla ilgili hususlar ise; araştırmacının a) sadece katılımcılardan toplanan bilgiyi temel alarak kodları geliştirmesi b)önceden belirlenmiş kodları 
kullanması, sonra verileri bu kodlara uygun hale getirmesi veya c) ortaya ç1kan ve önceden belirlenmiş kodların bir kombinasyonunu kullanmasıdır (Creswell, 2016, s, 199). Yukarıda "a" seçeneğinde yapılan açıklamalarla uyumlu olarak bu çalışmada araştırmacı bu çalışmanın veri kaynağını oluşturan dokümanları dikkatli bir biçimde inceleyerek çalışmanın kod ve kategorilerini oluşturdu

1. Verilerin kodlanması,

2. Temaların bulunması,

3. Kodların ve temaların düzenlenmesi,

4. Bulguların tanımlanması ve yorumlanması (Yıldırım ve Şimşek, 2013, s.260).

\section{Verilerin Kodlanması ve Temaların Bulunması}

Çalışmada İbrahim Örs'ün eserlerinden elde edilen verilerin kodlanmasında, "Verilerden çıkarılan kavramlara göre yapılan kodlama" kullanılmıştır. Şimşek ve Yıldırım'a göre "Bu tür araştırmalarda araştırmacı, verileri satır satır okur ve araştırmanın amacı çerçevesinde önemli olan boyutları saptamaya çalışır. Ortaya çkan anlama göre araştırmacı, belirli kodlar üretir ya da doğrudan verilerden yola çıkarak kodlar oluşturur." (Şimsek ve Yıldırım, 2013, s.264).

İbrahim Örs'ün eserlerinde yer alan eğitsel iletiler benzer ve ortak yönleri bakımından ele alınarak kategoriler oluşturuldu. Kodların hangi kategorilere dâhil edileceği hususunda alan eğitimi uzmanlarının ve deneyimli Türkçe öğretmenlerinin görüşlerine başvurularak tüm kodlar kategorilerle ilişkilendirildi. Örneğin "Yardımsever olmak" ve "Dayanışma içinde olmak" iletilerinin hangi kategorilerle ilişkilendirileceği uzmanlarla tartışıldı. Tartışma sonunda "Yardımsever olmak" iletisinin bir kişilik özelliği olmasından dolayı kişisel gelişimi desteklemeye yönelik iletiler kategorisiyle ilişkilendirilmesi konusunda uzlaşmaya varılırken "Dayanışma içinde olmak" iletisinin 2 veya daha fazla kişiyi ilgilendiren bir davranış olmasından dolayı için toplumsal gelişimi destekleyen iletiler kategorisi ile ilişkilendirilmesi hususunda görüş birliğine varıldı. Diğer iletilerin ilişkilendirilmesinde de uzmanların ortak kanıya vardıkları noktalar belirleyici özellik olarak sayıldı. Örneğin, ulusal bilincin gelişmesine yönelik iletilerin ilişkilendirilmesinde, iletinin "Atatürk'ü sevmek" gibi bir millete özgü olup olmaması dikkate alınarak ilişkilendirme 
yapıldı. Eğer ileti "Ağaçları sevmek ve korumak" gibi bireyde çevre bilinci oluşturmaya yönelikse çevre bilincini desteklemeye yönelik ileti kategorisi ile ilişkilendirilirken "Barışı savunmak" gibi tüm insanlığa yönelik bir anlam taşıyorsa evrensel düşüncenin gelişimine yönelik ileti kategorisi ile ilişkilendirildi. Her ileti kategorisine bir kod verilip her kategorinin altında yer alan iletilere kod numarası tanımlandı. İletiler amaçlarına göre beş gruba ayrıldı.

\section{Amaçlarına Göre Eğitsel İletiler}

Her bir ileti kategorisi ilk harfleri esas alınarak kodlanmış, kategoriler altıda yer alan iletiler başına ait olduğu kategorinin baş harfi getirilerek numaralandırılmıştır.

"Amaçlarına Göre Eğitsel İletiler" in kodlaması şu şekilde yapılmıştır:

1. Kişisel gelişimi destekleyen eğitsel iletiler " $K$ " harfi ile kodlanmıştır.

2. Toplumsal gelişimi destekleyen eğitsel iletiler " $\mathrm{T}$ ” harfi ile kodlanmıştir.

3. Ulusal düşüncenin gelişimini destekleyen eğitsel iletiler " $U$ " harfi ile kodlanmıştır.

4. Çevre bilinci gelişimini destekleyen eğitsel iletiler "Ç" harfi ile kodlanmiştır.

5. Evrensel düşüncenin gelişimini destekleyen eğitsel iletiler " $E$ " harfi ile kodlanmıştır.

\section{Kodların ve Temaların Düzenlenmesi}

Araştırmada incelenen eserlerde tespit edilen eğitsel iletiler kategorilere ayr1lıp kodlandıktan sonra oluşan tablolar şu şekildedir:

\section{Kişisel Gelişimi Destekleyen Eğitsel İletilerle İlgili Kodlarn Düzenlen-} mesi: TDK Bilim ve Sanat Terimleri Sözlügü̈’nde “Bireyin, toplam kalite felsefesini kendi yaşantısına uyarlayarak, küçük küçük adımlarla da olsa günden güne ilerlemeler kaydetmesi, önüne çıkan engellerden dersini alarak belirlediği kişisel vizyonuna ulaşabilmesi durumu."(http://sozluk.gov.tr/. Erişim tarihi: 18.06.2019) olarak tanımlanan kişisel gelişim bireyin kendi kendini geliştirmesidir. Yazılı eserler de bireyin kendini geliştirmesine yardım ettiği 
için incelenen eserlerde kişisel gelişimi desteklenmeye yönelik iletilerin tespiti de amaçlanmıştır.

\section{Toplumsal Gelişimi Destekleyen İletiler İle İlgili Kodlarn Düzenlenmesi:} Birey içinde yaşadığı toplumdan ayrı düşünülemez. Bireyin kazanımları bir yandan kendini geliştirirken diğer taraftan da içinde yaşadığı topluma da pozitif katkı yapar. Bu ileti alanı ile ilişkilendirilen iletiler en az iki ve daha fazla kişiyi etkilemesi göz önüne alınarak bu kategori ile ilişkilendirilmiştir.

\section{3. Çevre Bilincinin Gelişmesini Destekleyen İletiler İle İlgili Kodlarn Düzen-} lenmesi: İçinde yaşadığı çevre birey için önemli bir unsurdur. Korunması ve yaşanılır olması birey için önemlidir. Bu sebeple incelenen eserlerde tespit edilmeye çalışılan bu kategorideki iletilerin ilişkilendirilmesinde çevre bilinci geliştirmeye yönelik olma özelliği göz önünde bulunduruldu.

\section{Ulusal Bilincin Gelişmesini Destekleyen Eğitsel İletiler İle İlgili Kodlarn} Düzenlenmesi: Bireyin mensubu olduğu ulusun değer yargılarını taşıması, kendi ulusuna ait maddi ve manevi kültür ürünlerini tanıması, ulusal benliğini koruması birey için önemlidir. Bu sebeple incelemeye dâhil edilen bu kategorideki iletiler ilişkilendirilirken iletinin bir ulusa ait özelliği taşıması göz önünde bulundurulmuştur.

\section{Evrensel Düşüncenin Gelişimini Destekleyen İletiler İle İlgili Kodlarnn Dü-} zenlenmesi: Bu kategori eserde tüm insanlığa yönelik iletilerinin tespiti için konulmuştur. İletiler ilişkilendirilirken bu husus göz önünde bulundurulmuştur.

\section{İbrahim ÖRS'ün Eserlerinde Yer Alan Eğitsel İletilere Dair Genel Bul- gular ve Yorumlar}

Bu bölümde İbrahim Örs'ün çocuklara yönelik eserlerinde yer alan eğitsel iletilere dair bulgulara yer verilmiş ve bulgular yorumlanmıştır.

Yapılan incelemeden sonra tespit edilen bulgular tablolar halinde verilmiştir. Eserlerin tablo ve grafiklerdeki diziliş sırası, ilk yayın tarihlerine bakılarak en eskiden en yeniye olacak şekilde oluşturulmuştur. 


\section{Alt Problem İle İlgili Tüm Eserlerde Tespit Edilen Genel Bulgular ve Yorumlar}

Yazarın incelenen eserlerinde bu alt problem kategorisi ile ilgili 394 ileti tespit edildi. Bu kategori, yazarın eserlerinde en çok ileti tespit edilen kategoridir. $\mathrm{Bu}$ kategorideki iletilerin eserlere göre dağılımını Grafik 1'de gösterilmiştir.

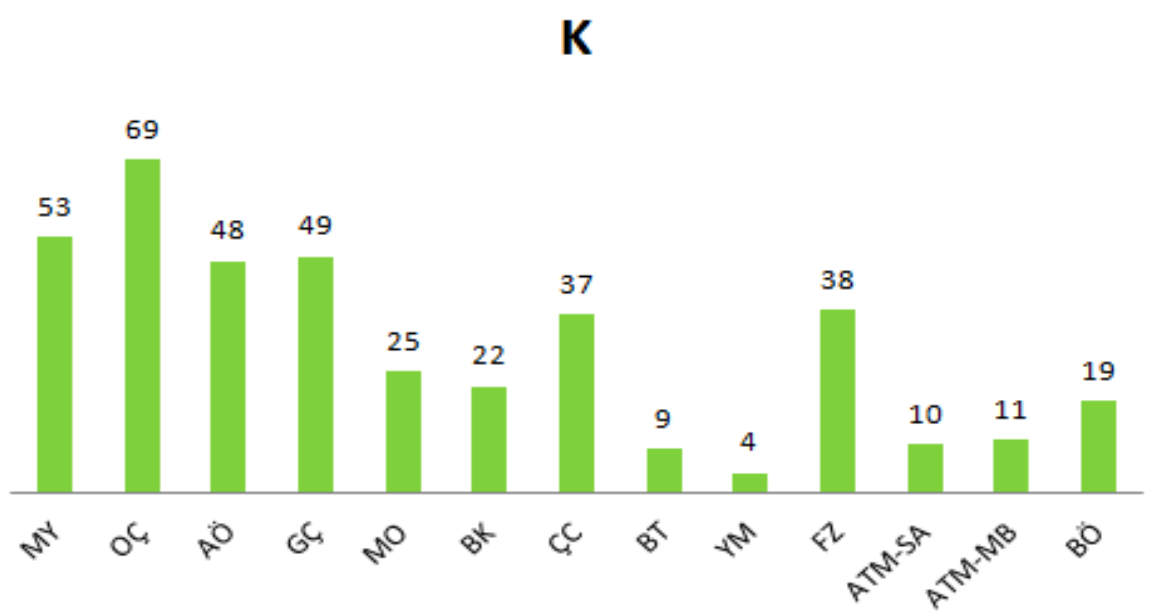

Şekil 1. Tüm Eserlerde Tespit Edilen 1. Alt Problemle İlgili Eğitsel İletilerin Eserlere Göre Dă̆ılımı

Şekil 1 incelendiğinde 1. alt problem kategorisinde en fazla ileti içeren eserin 69 ileti ile "Onur Çocuğu" adlı eser olduğu görülmektedir. Bu eseri 53 ileti ile "Muhtarın Yeğenleri" adlı eser, 49 ileti ile "Göl Çocukları" adlı eser takip etmektedir.Bu üç eserin çocuk kahramanları kişilik özellikleri açısından güçlü karakterlerdir.

"Onur Çocuğu" adlı eserde babasını erken yaşta kaybetmiş bir çocuğun kendi ayakları üzerinde durabilme mücadelesi anlatılmaktadır. Korhan, onurlu ve çalışkan bir çocuktur.

"Muhtarın Yeğenleri" adlı eserde yer alan Utku ile Tutku adlı çocuk kahramanlar, gösterdikleri çaba ile köyde düşman iki ağanın barışmasını sağlamışlardır. İki kahraman da girişken, lider ruhlu ve akıllıdır.

"Göl Çocukları" adlı eserin ana karakteri Selçuk ve Duygu, köylerine gelen Kurt Goldman adlı Alman turistin, aslında bir tarihi eser kaçakçısı 
olduğunu ortaya çıkarmıştır. Bu kahramanlar cesur, girişken, fedakâr ve millî duygularla hareket etmektedir.

$\mathrm{Bu}$ kategorideki iletilerin tüm eserlerde yer alan kullanım sıklıkları, kategori içindeki ve tespit edilen tüm iletiler içindeki oranlarını ayrıntılı olarak gösteren bilgiler Tablo 2'de sunulmuştur.

Tablo 2. Eserlerin tamamında tespit edilen 1. alt problemle ilgili eğitsel iletilerin kullanım siklik ve oranları

\begin{tabular}{|c|c|c|c|c|}
\hline İleti Kodu & İleti Adı & $f$ & $\% \mathrm{~K}$ & \%Toplam \\
\hline K1. & Hoşgörülü olmak & 1 & $0,25 \%$ & $0,13 \%$ \\
\hline K2. & Yalan söylememek & 14 & $3,55 \%$ & $1,80 \%$ \\
\hline K3. & Teşekkür etmek & 13 & $3,30 \%$ & $1,68 \%$ \\
\hline K4. & Okumayı sevmek & 10 & $2,54 \%$ & $1,29 \%$ \\
\hline K5. & Tatlı dilli olmak & 1 & $0,25 \%$ & $0,13 \%$ \\
\hline K6. & Öz güvenli olmak & 7 & $1,78 \%$ & $0,90 \%$ \\
\hline K7. & Okulu sevmek & 10 & $2,54 \%$ & $1,29 \%$ \\
\hline K8. & Utangaç olmamak & 3 & $0,76 \%$ & $0,39 \%$ \\
\hline K9. & Umutlu olmak & 18 & $4,57 \%$ & $2,32 \%$ \\
\hline K10. & Şüpheci olmak & 10 & $2,54 \%$ & $1,29 \%$ \\
\hline K11. & Meraklı olmak & 6 & $1,52 \%$ & $0,77 \%$ \\
\hline K12. & Başarılı olmak & 14 & $3,55 \%$ & $1,80 \%$ \\
\hline K13. & Takdir etmek & 18 & $4,57 \%$ & $2,32 \%$ \\
\hline K14. & İnançlı olmak & 7 & $1,78 \%$ & $0,90 \%$ \\
\hline K15. & İstikrarlı olmak & 1 & $0,25 \%$ & $0,13 \%$ \\
\hline K16. & Pişmanlık duygusuna sahip olmak & 9 & $2,28 \%$ & $1,16 \%$ \\
\hline K17. & Oyun oynamak & 19 & $4,82 \%$ & $2,45 \%$ \\
\hline K18. & Tasarruf etmek & 1 & $0,25 \%$ & $0,13 \%$ \\
\hline K19. & Sorumluluk sahibi olmak & 8 & $2,03 \%$ & $1,03 \%$ \\
\hline K20. & Çalışkan olmak & 3 & $0,76 \%$ & $0,39 \%$ \\
\hline K21. & Sevgi dolu olmak & 1 & $0,25 \%$ & $0,13 \%$ \\
\hline K22. & Özür dilemek & 3 & $0,76 \%$ & $0,39 \%$ \\
\hline K23. & İyilik yapmak & 9 & $2,28 \%$ & $1,16 \%$ \\
\hline K24. & İftira atmamak & 2 & $0,51 \%$ & $0,26 \%$ \\
\hline K25. & Yabancı dil bilmek & 2 & $0,51 \%$ & $0,26 \%$ \\
\hline K26. & Dürüst ve güvenilir olmak & 2 & $0,51 \%$ & $0,26 \%$ \\
\hline K27. & Temizliğe önem vermek & 1 & $0,25 \%$ & $0,13 \%$ \\
\hline K28. & Kararlı olmak & 9 & $2,28 \%$ & $1,16 \%$ \\
\hline K29. & Sağlığına dikkat etmek & 10 & $2,54 \%$ & $1,29 \%$ \\
\hline K30. & Hatalarından ders çıkarmak & 1 & $0,25 \%$ & $0,13 \%$ \\
\hline K31. & Yeme alışkanlıklarına dikkat etmek & 3 & $0,76 \%$ & $0,39 \%$ \\
\hline K32. & İdealist olmak & 5 & $1,27 \%$ & $0,64 \%$ \\
\hline K33. & Eğitimli olmak & 6 & $1,52 \%$ & $0,77 \%$ \\
\hline K34. & Örnek davranışlar sergilemek & 6 & $1,52 \%$ & $0,77 \%$ \\
\hline K35. & Sayg1 göstermek & 1 & $0,25 \%$ & $0,13 \%$ \\
\hline K36. & Yardımsever olmak & 10 & $2,54 \%$ & $1,29 \%$ \\
\hline
\end{tabular}




\begin{tabular}{lllll}
\hline K37. & İkram etmek & 3 & $0,76 \%$ & $0,39 \%$ \\
K38. & Mutlu olmak & 33 & $8,38 \%$ & $4,25 \%$ \\
K39. & Ön yarg1l olmamak & 7 & $1,78 \%$ & $0,90 \%$ \\
K40. & Sabirl olmak & 4 & $1,02 \%$ & $0,52 \%$ \\
K41. & Sözünde durmak & 3 & $0,76 \%$ & $0,39 \%$ \\
K42. & İleri görüşlü olmak & 5 & $1,27 \%$ & $0,64 \%$ \\
K43. & Tedbirli olmak & 3 & $0,76 \%$ & $0,39 \%$ \\
K44. & Soğukkanlı olmak & 1 & $0,25 \%$ & $0,13 \%$ \\
K45. & Öfke kontrolünü sağlamak & 7 & $1,78 \%$ & $0,90 \%$ \\
K46. & Kin tutmamak & 8 & $2,03 \%$ & $1,03 \%$ \\
K47. & Vefalı olmak & 3 & $0,76 \%$ & $0,39 \%$ \\
K48. & Alçak gönüllü olmak & 2 & $0,51 \%$ & $0,26 \%$ \\
K49. & Girişimci olmak & 6 & $1,52 \%$ & $0,77 \%$ \\
K50. & Cesaretli olmak & 11 & $2,79 \%$ & $1,42 \%$ \\
K51. & Onurlu olmak & 9 & $2,28 \%$ & $1,16 \%$ \\
K52. & Gururlanmak & 4 & $1,02 \%$ & $0,52 \%$ \\
K53. & Ödül almak & 5 & $1,27 \%$ & $0,64 \%$ \\
K54. & Hakkını savunmak & 2 & $0,51 \%$ & $0,26 \%$ \\
K55. & Bencil olmamak & 1 & $0,25 \%$ & $0,13 \%$ \\
K56. & Karar alma becerisine sahip olmak & 6 & $1,52 \%$ & $0,77 \%$ \\
K57. & Liderlik yapmak & 6 & $1,52 \%$ & $0,77 \%$ \\
K58. & İyimser olmak & 4 & $1,02 \%$ & $0,52 \%$ \\
K59. & Taraftar olmak & 1 & $0,25 \%$ & $0,13 \%$ \\
K60. & Yazmayı sevmek & 1 & $0,25 \%$ & $0,13 \%$ \\
K61. & Sir saklamak & 1 & $0,25 \%$ & $0,13 \%$ \\
K62. & Zamanı yönetmek & 7 & $1,78 \%$ & $0,90 \%$ \\
K63. & Kendini tanımak & 7 & $1,78 \%$ & $0,90 \%$ \\
\hline Toplam & & 394 & $\mathbf{1 0 0 , 0 0} \%$ & $\mathbf{5 0 , 7 7 \%}$ \\
\hline & & & & \\
\hline & & & & \\
\hline
\end{tabular}

Tablo incelendiğinde, yazarın eserlerinde tespit edilen 394 kişisel gelişimi destekleyen iletiden en fazla frekansa sahip olan ileti "Mutlu olmak"(33) iletisidir. Bu iletiyi sırasiyla "Oyun oynamak" (19), "Umutlu olmak" ve "Takdir etmek" (18) iletileri takip etmektedir. Bu dört iletinin toplamı, bu ileti kategorisinin \% 22' sini oluşturmaktadır.

Yazarın eserleri mutlu sonla biter. Kahramanlar eser boyunca mücadelesini verdikleri şey her neyse onu elde etmek için umutların kaybetmeyip sonunda ona ulaşır. Kahramanların olumlu davranışları, başarıları; akran, aile ve sosyal çevreleri tarafından takdir edilir. Eserlerde çocukların oynadıkları oyunlara da sıkça yer verilmiştir.

Ayrica bu ileti kategorisinde bulunan 394 ileti, eserlerin tamamında bulunan 776 iletinin \% 50,77'sini oluşturmaktadır. Bu oran, yazarın okuyucusuna 
en fazla ileti verdiği kategorinin kişisel gelişimi destekleyen iletiler kategorisi olduğu sonucunu ortaya çıkarmaktadır.

\section{Alt Problem ile İlgili Tüm Eserlerde Tespit Edilen Genel Bulgular ve Yorumlar}

İncelenen eserlerde bu kategori ile ilgili 155 ileti tespit edilmiştir. Bu kategorideki iletilerin eserlere göre dağılımını Şekil 2' de gösterilmiştir

$\mathbf{T}$

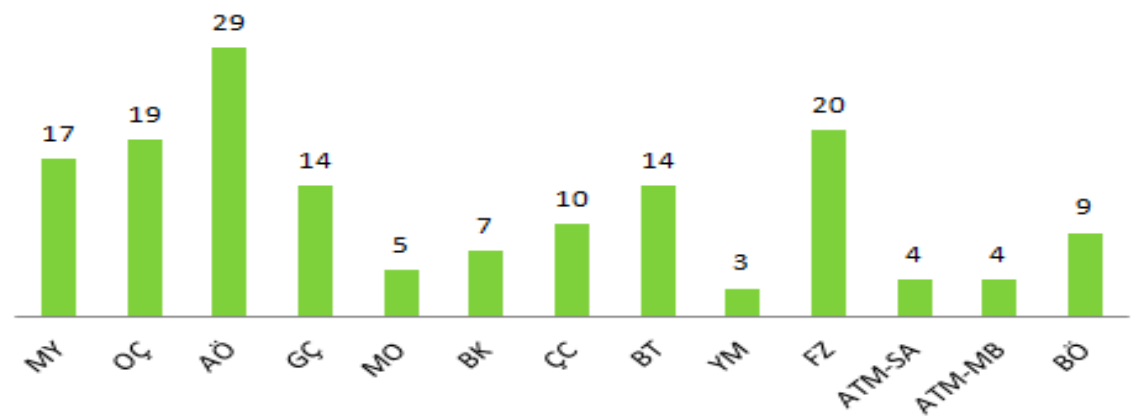

Şekil 2. Tüm eserlerde tespit edilen 2. alt problemle ilgili ĕgitsel iletilerin eserlere göre dă̆ılımı

Şekil 2. incelendiğinde bu kategoride yer alan iletileri en çok içeren eserin 29 ileti ile "Almanya Öyküsü" adlı eser olduğu görülmektedir. Bu eseri 20 ileti ile "Fındık Zamanı" ve 19 ileti ile "Onur Çocuğu" adlı eserler takip etmektedir.

"Almanya Öyküsü" adlı eserde Almanya'ya çalışmak amacıyla giden bir ailenin başından geçenler anlatılmaktadır. Eserde oraya çalışmak için gitmiş başka Türk ailelerin ve başka ülkelerden gelmiş işçi ailelerin sosyal yaşamı, kültürel açıdan yozlaşmaları, yaşadıkları toplumsal sorunlara değinilmektedir. Bu sebeple toplumsal gelişime yönelik iletilerin bu eserde sıkça yer aldı̆̆ görülmektedir.

"Fındık Zamanı" adlı eserde ise Karadeniz'in bir köyüne fındık toplamak için göç eden aileler ile köyün yerlileri arasında geçen olaylar anlatılmaktadır. Eserde köylülerin gelenek ve görenekleri tanitılmakta, uygun görülmeyen 
toplumsal kabuller eleştirel bir şekilde sunulmaktadır. Bu sebeple eserde bu ileti kategorisi ile ilgili iletilerin sıkça bulunduğu görülmektedir.

$\mathrm{Bu}$ kategorideki iletilerin tüm eserlerde yer alan kullanım sıklıkları, kategori içindeki ve tespit edilen tüm iletiler içindeki oranlarını ayrıntılı olarak gösteren bilgiler Tablo 8'de sunulmuştur.

Tablo 8 incelendiğinde bu kategoride en çok frekansa sahip olan iletinin, 23 ileti ile "Toplumun sosyal yaşamını tanımak" iletisi olduğu görülmektedir. Bu iletiyi 16 frekans ile "Eğitim sorunlarını gidermek" ve "Anne babayı sevmek" iletileri takip etmektedir.

Yazar, eserlerinde toplumun sosyal yaşamını okuyucularına tanıtmıştır. Toplumun aksayan yönleri de eleştirel bir şekilde eserlerde işlenmiştir. Buradan hareketle yazarın okurlarına toplumun sosyal yaşamını tanıtmayı hedeflediği söylenebilir.

Bu kategori ile ilgili olarak yazarın üzerinde durduğu bir diğer husus eğitim sorunlarıdır. Yazar, 1970'li ve 1980'li yıllarda kaleme aldığı eserlerinde o yıllarda yaşanan eğitim sorunlarına değinmiştir. Bu sorunların başında da okul eksikliği gelmektedir. Eserlerde yer alan ve çoğunlukla köyde yaşayan çocuk kahramanlar, ilkokulu bitirdikten sonra bu sorunla karşı karşıya kalmaktadır. Köylerde ortaokulun olmaması ve bu sebeple çocukların okula gidememesi yazarın eserlerinde vurguladığı bir eğitim sorunudur.

Ayrıca yazarın hemen hemen her eserinde şahıs kadrosunun içinde bir “öğretmen” karakteri bulunmaktadır. Eserlerde öğretmen; yol gösterici, akıl danışılan, çocukların eğitimi için çaba gösteren, bulunduğu köy veya kasaba ile ilgili alınacak kararlarda etkisi olan ve herkes tarafından sevilen biri olarak yer almaktadır. Yazarın özellikle eğitim, eğitim sorunları, öğretmen sevgisi gibi konuları eserlerinde işlemesinin onun eğitimci bir yazar olmasından kaynaklandığ1 düşünülmektedir. Çünkü yazar yüksek öğrenimini Gazi Eğitim Enstitüsünde tamamlamıştır. 
Tablo 3. Eserlerin Tamamında Tespit Edilen 2. Alt Problemle İlgili Ĕ̆itsel İletilerin Kullanım Siklık ve Oranları

\begin{tabular}{lllll}
\hline İleti & İleti Adi & f & \% & \% \\
Kodu & & Toplam \\
\hline T1. & Anne babayı sevmek & 16 & $10,32 \%$ & $2,06 \%$ \\
T2. & Öğretmeni sevmek & 12 & $7,74 \%$ & $1,55 \%$ \\
T3. & Eğitim sistemini tanımak & 4 & $2,58 \%$ & $0,52 \%$ \\
T4. & Komşuluk ilişkilerini yaşatmak & 2 & $1,29 \%$ & $0,26 \%$ \\
T5. & Çocuğa ebeveyn ilgisi göstermek & 7 & $4,52 \%$ & $0,90 \%$ \\
T6. & Eğitim sorunlarını gidermek & 16 & $10,32 \%$ & $2,06 \%$ \\
T7. & Öğretmen niteliğini artırmak & 1 & $0,65 \%$ & $0,13 \%$ \\
T8. & Olumlu iletişim kurmak & 5 & $3,23 \%$ & $0,64 \%$ \\
T9. & Zararlı alışkanlıklardan kaçınmak & 4 & $2,58 \%$ & $0,52 \%$ \\
T10. & Empati kurmak & 2 & $1,29 \%$ & $0,26 \%$ \\
T11. & Iletişim araçlarından faydalanmak & 5 & $3,23 \%$ & $0,64 \%$ \\
T12. & Hediyeleşmek & 3 & $1,94 \%$ & $0,39 \%$ \\
T13. & Eğitimde firsat eşitliğini sağlamak & 1 & $0,65 \%$ & $0,13 \%$ \\
T14. & Dayanışma içinde olmak & 10 & $6,45 \%$ & $1,29 \%$ \\
T15. & Konuksever olmak & 5 & $3,23 \%$ & $0,64 \%$ \\
T16. & Yerleşim yerlerini geliştirmek & 3 & $1,94 \%$ & $0,39 \%$ \\
T17. & Yardımlaşmak & 1 & $0,65 \%$ & $0,13 \%$ \\
T18. & Hastaları ziyaret etmek & 2 & $1,29 \%$ & $0,26 \%$ \\
T19. & Alçak gönüllü olmak & 2 & $1,29 \%$ & $0,26 \%$ \\
T20. & Anne baba sözü dinlemek & 1 & $0,65 \%$ & $0,13 \%$ \\
T21. & Alay etmemek & 2 & $1,29 \%$ & $0,26 \%$ \\
T22. & Toplumun sosyal yaşamını tanımak & 23 & $14,84 \%$ & $2,96 \%$ \\
T23. & Büyüklere sayg1 göstermek & 5 & $3,23 \%$ & $0,64 \%$ \\
T24. & Arkadaşlı̆̆a ve dostluğa önem vermek & 14 & $9,03 \%$ & $1,80 \%$ \\
T25. & Kardeşlerini sevmek & 2 & $1,29 \%$ & $0,26 \%$ \\
T26. & Yoksullukla başa çımak & 7 & $4,52 \%$ & $0,90 \%$ \\
\hline Toplam & & $\mathbf{1 5 5}$ & $\mathbf{1 0 0 , 0 0} \%$ & $\mathbf{1 9 , 9 7 \%}$ \\
\hline
\end{tabular}

Bu kategoride sıkça yer alan bir diğer ileti anne ve baba sevgisidir. Eserlerde yer alan çocuk kahramanlar genel olarak anne ve babalarını çok seven, mutlu bir aile hayatına sahip kişilerdir. Aynı zamanda onlar da anne ve babaları tarafından sevilmektedir. Toplumun içinde ailenin önemi düşünüldüğünde yazarın eserlerinde mutlu bir aile, mutlu bir toplum vurgusu yaptığ söylenebilir.

Bu kategoride tespit edilen 155 ileti, toplam ileti sayısının \% 19,97'sini oluşturmaktadır. Bu oranla bu kategori, ileti sayısı bakımından 2. sırada yer almaktadır. 


\section{Alt Problem ile İlgili Tüm Eserlerde Tespit Edilen Genel Bulgular ve Yorumlar}

İncelenen eserlerde, bu ileti kategorisi ile ilgili 97 ileti tespit edilmiştir. Bu kategorideki iletilerin incelenen eserlerde yer alan sayıları Şekil 3'te gösterilmiştir.

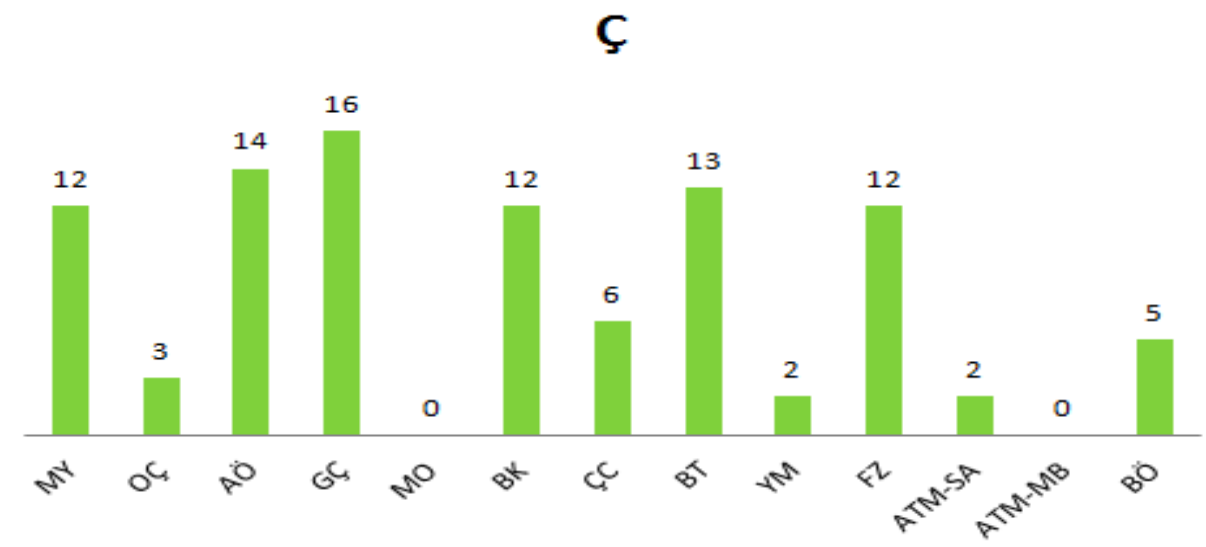

Şekil 3. Tüm eserlerde tespit edilen 3. alt problemle ilgili eğitsel iletilerin eserlere göre dă̆ılımı

Şekil 3'e göre çevre bilinci gelişimini destekleyen eğitsel iletiler kategorisinde en çok ileti tespit edilen eser 16 ileti ile "Göl Çocukları" adlı eserdir. Bu eseri 14 ileti ile "Almanya Öyküsü" ve 13 ileti ile "Büyük Tutku" adlı eserler takip etmektedir.

"Göl Çocukları" adlı eserde Gölüstü köyüne gelen Kurt Goldman adında Alman bir turistin gölde yer alan tarihi bir eseri kaçırmak istemesi anlatılmaktadır. Olaylar anlatılırken çevrenin özelliklerine sık sık değinilmiş, özellikle hayvan sevgisi ön plana çıkarılmıştır. Eserde Selçuk'un köpeği Arap'ın olayın ortaya çıkarılmasında katkısı vardır. Bütün bunlar eserin bu kategori ile ilgili ileti bakımından zengin olmasını sağlamıştır.

"Almanya Öyküsü" adlı eserde de bu kategori ile ilgili olarak Almanya'da çalışan işçilerin yaşadığı çevrenin özellikleri, hayvan sevgisi gibi konulara yer verilmiştir.

Bu ileti kategorisinde, "Mücahitin Oğlu” ve "Atıl'ın Maceraları- Mavi Bisiklet" adlı eserlerde herhangi bir ileti tespit edilememiştir. Bu kategorideki 
iletilerin tüm eserlerde yer alan kullanım sıklıklarını, kategori içindeki ve tespit edilen tüm iletiler içindeki oranlarını ayrıntılı olarak gösteren bilgiler Tablo 3'da sunulmuştur.

Tablo 3. Eserlerin Tamamında Tespit Edilen 3. Alt Problemle İlgili Ĕ̆itsel İletilerin Kullanım Siklik ve Oranları

\begin{tabular}{lllll}
\hline İleti Kodu & İleti Adı & f & \%Ç & \%Toplam \\
\hline Ç1. & Hayvanları sevmek ve korumak & 32 & $32,99 \%$ & $4,12 \%$ \\
Ç2. & Ağaçları sevmek ve korumak & 6 & $6,19 \%$ & $0,77 \%$ \\
Ç3. & Mekânları tanımak & 18 & $18,56 \%$ & $2,32 \%$ \\
Ç4. & Doğa olaylarını tanımak & 9 & $9,28 \%$ & $1,16 \%$ \\
Ç5. & Köy yaşamını tanımak & 10 & $10,31 \%$ & $1,29 \%$ \\
Ç6. & Çevrenin özelliklerini tanımak & 10 & $10,31 \%$ & $1,29 \%$ \\
Ç7. & Çevreyi korumak & 3 & $3,09 \%$ & $0,39 \%$ \\
Ç8. & Çevreyi temiz tutmak & 2 & $2,06 \%$ & $0,26 \%$ \\
Ç9. & Mevsimleri tanımak & 6 & $6,19 \%$ & $0,77 \%$ \\
Ç10. & Doğal afetleri tanımak & 1 & $1,03 \%$ & $0,13 \%$ \\
\hline Toplam & & $\mathbf{9 7}$ & $\mathbf{1 0 0 , 0 0 \%}$ & $\mathbf{1 2 , 5 0 \%}$ \\
\hline
\end{tabular}

Tablo 3 incelendiğinde bu eğitsel ileti kategorisinde en çok tespit edilen iletinin 32 ileti sayısı ile "Hayvanları sevmek ve korumak" iletisi olduğu görülmektedir. Ardından 18 ileti ile "Mekânları tanımak" iletisi gelmektedir.

"Hayvanları sevmek ve korumak" iletisinin 32 defa tekrar etmesi yazarın hayvanlara verdiği önemi göstermektedir. Yazarın hemen hemen bütün eserlerinde bir hayvan bulunmaktadır. Bu hayvanlar sahipleri olan çocuk kahramanların yardımcılarıdır. Kimi zaman eserdeki olayın gelişimine etki etmektedirler. Göl Çocukları adlı eserde Selçuk'un köpeği Arap'ın, Kurt Goldman'ın göl üzerine bıraktığı tahta işareti yüzerek sahibinin ulaşacağı yere getirmesi, Büyük Tutku adlı eserde Haydut adındaki köpeğin Gülfem'i kurdun saldırısından kurtarması; Almanya Öyküsü adlı eserde kaybolan Gülfem'in Kaya'nın Boncuk adlı köpeği tarafından bulunması bu duruma örnek olarak verilebilir.

Yine bu kategoride yer alan "Köy yaşamını tanımak" iletisi yazarın eserlerinde sıkça yer verdiği bir diğer ileti türüdür. Köyün doğal güzelliği, fiziki yapısı, fiziki şartların insan yaşamına etkisi yazarın eserlerinde değindiği noktalardır. "Çevre" konusu kimi zaman doğrudan kimi zaman dolaylı şekilde sunulan iletilerle incelenen eserlerde yer almaktadır. Eserlerde çevre ile 
ilgili betimlemeler oldukça canlıdır. Bu kategoride tespit edilen 97 ileti, toplam ileti sayısının \%12,5'ini oluşturmaktadır.

\section{Alt Problem İle İlgili Tüm Eserlerde Tespit Edilen Genel Bulgular ve Yorumlar}

Yazarın eserlerinde bu ileti kategorisi ile ilgili toplam 57 ileti tespit edilmiştir. 57 iletinin eserlere göre dağglımı Şekil 4'te sunulmuştur.

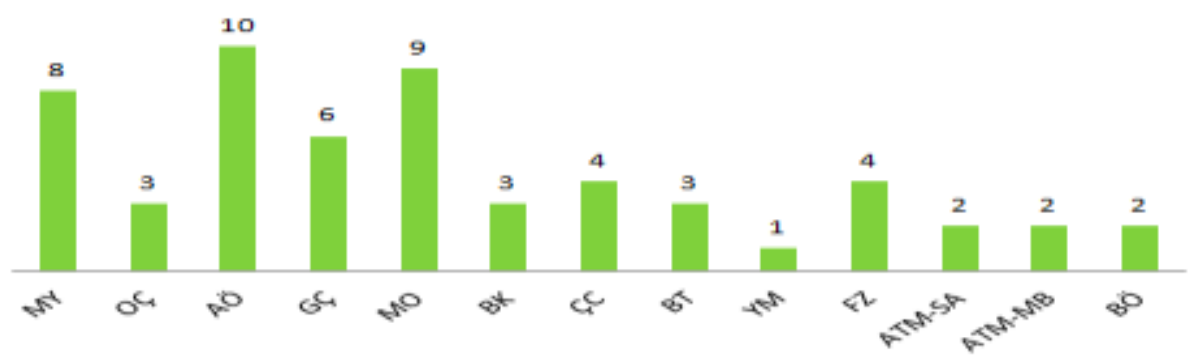

Şekil 4. Tüm Eserlerde Tespit Edilen 4. Alt Problemle İlgili Eğitsel İletilerin Eserlere Göre Dă̆ılımı

Şekil 4'e göre bu kategorideki iletilerin en çok yer aldığı eser 10 ileti ile "Almanya Öyküsü" adlı eserdir. Bu eseri 9 ileti ile "Mücahitin Oğlu" ve 8 ileti ile "Muhtarın Yeğenleri" adlı eserler takip etmektedir. Toplam 57 ileti tespit edilen bu kategori, bu oran ile belirlenen beş kategori arasında beşinci sırada yer almaktadır.

Bu kategori ile ilgili ileti bakımından ilk sırada yer alan Almanya Öyküsü adlı eserde Almanya'ya çalışmak için giden bir ailenin başından geçenler anlatılmaktadır.

Genel (2014)'e göre Türkiye'den Almanya' ya yapılan ilk işçi göçünün başlangıç tarihi olarak "31 Ekim 1961 İş Gücü Anlaşması" kabul edilmektedir. Bununla birlikte resmi olmayıp bireysel girişim ya da aracılar vasıtasıyla yapılan göçün 1950'li yıllara kadar uzandığı bilinmektedir (Genel, 2014:6). 1975 yılında yayımlanan bu eserde 15-20 yıldır Almanya'da işçi olarak çalışan Türk ailelerinin ve çocuklarının millî değerlerini ve benliklerini kaybetmeleri, kültürel açıdan yozlaşmaları doğrudan ve dolaylı iletiler aracılı̆̆ıyla eleştirel 
bir açıdan ele alınmaktadır. Bu sebeple eserde ulusal düşüncenin gelişmesini destekleyen iletiler sıkça yer almıştır.

$\mathrm{Bu}$ kategorideki iletilerin tüm eserlerde yer alan kullanım sıklıklarını, kategori içindeki ve tespit edilen tüm iletiler içindeki oranlarını ayrıntılı olarak gösteren bilgiler Tablo 10'da sunulmuştur.

Tablo 4. Eserlerin Tamamında Tespit Edilen 4. Alt Problemle İlgili Eğitsel İletilerin Kullanım Sıklıkları ve Oranları

\begin{tabular}{lllll}
\hline İleti & \multicolumn{1}{c}{ İleti Ad1 } & $\mathbf{\%}$ & $\mathbf{\%}$ \\
Kodu & & f & U & Toplam \\
\hline U1. & Ulusal benliğini korumak & 4 & $7,02 \%$ & $0,52 \%$ \\
U2. & Ulusal kültür ürünlerini tanımak & 16 & $28,07 \%$ & $2,06 \%$ \\
U3. & Vatanı sevmek & 4 & $7,02 \%$ & $0,52 \%$ \\
U4. & Ana dilini sevmek ve korumak & 1 & $1,75 \%$ & $0,13 \%$ \\
U5. & Ulusal duygular taşımak & 13 & $22,81 \%$ & $1,68 \%$ \\
U6. & Ülke turizmine önem vermek & 1 & $1,75 \%$ & $0,13 \%$ \\
U7. & Atatürk'ü sevmek & 7 & $12,28 \%$ & $0,90 \%$ \\
U8. & Ülke menfaatlerini gözetmek & 2 & $3,51 \%$ & $0,26 \%$ \\
U9. & Tarihi eserlere önem vermek & 1 & $1,75 \%$ & $0,13 \%$ \\
U10. & Ulusal günlere önem vermek & 5 & $8,77 \%$ & $0,64 \%$ \\
U11. & Bayrağ1 sevmek & 3 & $5,26 \%$ & $0,39 \%$ \\
\hline Toplam & & $\mathbf{5 7}$ & $\mathbf{1 0 0 , 0 0 \%}$ & $\mathbf{7 , 3 5 \%}$ \\
\hline
\end{tabular}

Tablo 4 incelendiğinde bu kategoride en çok tespit edilen iletilerin 16 ileti ile "Ulusal kültür ürünlerini tanımak", 13 ileti ile "Ulusal duygular taşımak" ve 7 ileti ile "Atatürk'ü sevmek" olduğu görülmektedir.

Yazar eserlerinde Türk kültüründen, gelenek ve göreneklerinden örnekleri okuyucusuna aktarmıştır. Eserlerinde vatan sevgisi, bayrak sevgisi, millet sevgisi gibi konularda iletiler yer almaktadır.

"Atatürk'ü sevmek" iletisi bu kategoride en sik tekrarlanan bir diğer iletidir. Bir 23 Nisan Düşü adlı öyküde Atatürk ile ilgili şu sözler yazarın okuyucularına aktarmak istediği Atatürk sevgisini ortaya koymaktadır:

“Sayın Başkanımız, dedi Melekler, buyruğunuz üzere Türkiye'ye gittik. Atatürk'ü aradık, aradık sonunda bulduk. Ama kendisi için yapılmış olan Anıtkabir'de değildi. Ulusunun kalbindeydi. Orada yatıyordu bizi bağışlayınız. Onu oradan söküp alamadık. Ne denli uğraştıysak didindiysek olmadı. Bu bizim de gücümüz dışında bir şey." (BÖ, 2018:39)

57 ileti bulunan bu kategorinin toplam ileti sayısına oranı $\% 7,35^{\prime}$ tir. 


\section{Alt Problem ile İlgili Tüm Eserlerde Tespit Edilen Genel Bulgular}

Yazarın eserlerinde bu ileti kategorisi ile ilgili 73 ileti tespit edilmiştir. Bu iletilerin incelenen eserlere göre dağılımı Şekil 5'te sunulmuştur.

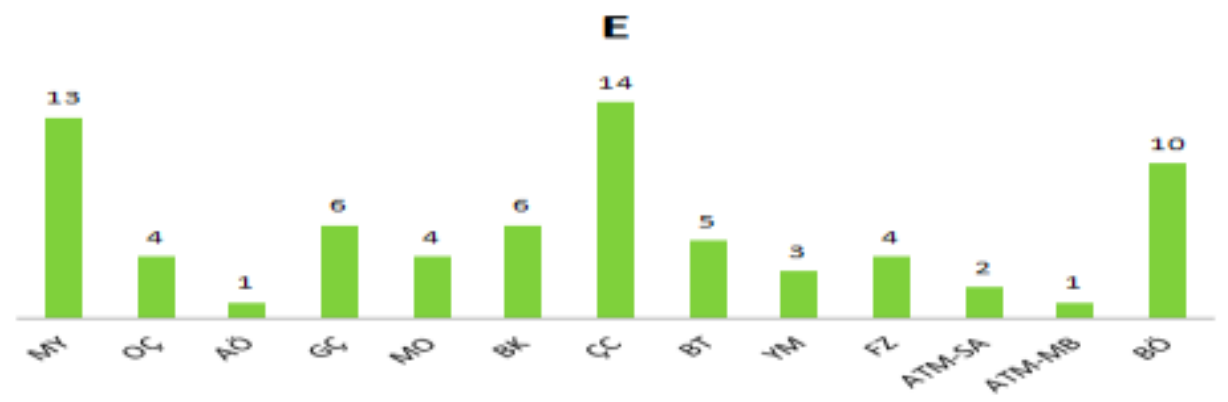

Şekil 5. Tüm eserlerde tespit edilen 5. alt problemle ilgili eğitsel iletilerin eserlere göre dă̆ılımı

Şekil 5'e göre, bu kategoride yer alan iletilerin en çok bulunduğu eser 14 ileti ile "Çocuk Cumhuriyeti" adlı eserdir. Bu eseri 13 ileti ile "Muhtarın Yeğenleri" ve 10 ileti ile "Bütün Öyküler" adlı eser takip etmektedir.

Bu kategori ile ilgili en çok ileti barındıran "Çocuk Cumhuriyeti" adlı eserde, Hakan Dağ adlı bir çocuk ve arkadaşlarının 1979 Dünya Çocuk Yılı dolayısıyla Birleşmiş Milletler tarafından bir Çocuk Cumhuriyeti kurulmasını sağlamak için verdikleri mücadele ve Çocuk Cumhuriyeti kurulduktan sonra çocuk adasında geçen olaylar anlatılmaktadır. Eserde bu kategori ile ilgili en çok vurgulanan ileti "Demokrasiyi savunmak" iletisidir. Çünkü Hakan Dağ'ın fikri ile hayata geçen Çocuk Cumhuriyeti'nde yönetim demokratik biçimde seçimle iş başına gelmekte, kararlar demokrasi gözetilerek alınmaktadır.

"Muhtarın Yeğenleri" adlı eserde ise birbirleriyle küs olan iki ailenin barışması anlatılmaktadır. Bu eserde barış, insan sevgisi ve demokrasi vurgusu yapılmıştır.

Bu kategorideki iletilerin tüm eserlerde yer alan kullanım sıklıkların, kategori içindeki ve tespit edilen tüm iletiler içindeki oranlarını ayrıntılı olarak gösteren bilgiler Tablo 5'de sunulmuştur. 
Tablo 5. Eserlerin tamamında tespit edilen 5. alt problemle ilgili eğitsel iletilerin kullanım sıklıkları ve oranları

\begin{tabular}{lllll}
\hline İleti Kodu & İleti Adı & $\mathbf{f}$ & $\mathbf{\% E}$ & $\mathbf{\% T o p l a m ~}$ \\
\hline E1. & Dürüst olmak & 1 & $1,37 \%$ & $0,13 \%$ \\
E2. & Merhametli olmak & 11 & $15,07 \%$ & $1,42 \%$ \\
E3. & Fedakâr olmak & 6 & $8,22 \%$ & $0,77 \%$ \\
E4. & Hirsılık yapmamak & 6 & $8,22 \%$ & $0,77 \%$ \\
E5. & Beden bütünlüğüne sayg1 duymak & 3 & $4,11 \%$ & $0,39 \%$ \\
E6. & Barışı savunmak & 13 & $17,81 \%$ & $1,68 \%$ \\
E7. & Duyarlı olmak & 5 & $6,85 \%$ & $0,64 \%$ \\
E8. & Adaletli olmak & 3 & $4,11 \%$ & $0,39 \%$ \\
E9. & Demokrasiyi savunmak & 8 & $10,96 \%$ & $1,03 \%$ \\
E10. & Bağımsız olmak & 2 & $2,74 \%$ & $0,26 \%$ \\
E11. & Sanatsever olmak & 4 & $5,48 \%$ & $0,52 \%$ \\
E12. & İnsan sevgisi taşımak & 4 & $5,48 \%$ & $0,52 \%$ \\
E13. & Çocuk haklarını bilmek & 2 & $2,74 \%$ & $0,26 \%$ \\
E14. & Çocuklara değer vermek & 2 & $2,74 \%$ & $0,26 \%$ \\
E15. & Eşitliği savunmak & 1 & $1,37 \%$ & $0,13 \%$ \\
E16. & Hak ve özgürlüklere sayg1 duymak & 2 & $2,74 \%$ & $0,26 \%$ \\
\hline Toplam & & 73 & $\mathbf{1 0 0 , 0 0} \%$ & $\mathbf{9 , 4 1 \%}$ \\
\hline
\end{tabular}

Tablo 5'e göre bu kategoride en çok tespit edilen iletiler 13 ileti ile "Barışı savunmak", 11 ileti ile "Merhametli olmak" ve 8 ileti ile "Demokrasiyi savunmak" iletileridir.

Yazarın eserlerinde bu kategori ile ilgili olarak vurgu yaptığı kavramların başında "Barış" gelmektedir. Muhtarın Yeğenleri adlı eserde köyde küs olan iki ağanın barışması ve bu barışmanın köye sağladığı fayda anlatılmaktadır.

Vurgulanan bir diğer ileti "Merhametli olmak" iletisidir. Merhamet duygusundan yoksun, kin ve nefret duygusu ile dolu olmak hem toplumsal hem de evrensel barışı olumsuz etkiler. Yazar bu iletilerle okurlarına merhametli olmanın olumlu sonuçlarını doğrudan ve dolaylı şekillerde aktarmıştır.

Bu kategoride yer alan 73 iletinin toplan ileti sayısina oranı $\% 9$, 41'dir.

\section{Sonuç ve Öneriler}

İbrahim Örs'ün incelenen 13 eserinde toplam 776 ileti tespit edilmiştir. Bu iletilerin 394'ü kişisel gelişimi destekleyen iletiler, 155'i toplumsal gelişimi destekleyen iletiler, 97'si çevresel gelişimi destekleyen iletiler, 57'si ulusal 
düşüncenin gelişimini destekleyen iletiler, 73'ü evrensel düşüncenin gelişimini destekleyen iletilerdir. Bu iletilerin dağılımı oransal olarak Şekil 6'da gösterilmiştir.

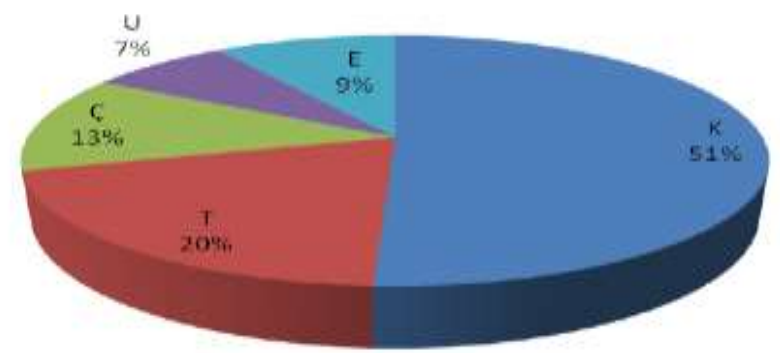

Şekil 6. İletilerin hedeflediği amaçlara göre dağılım oranları

Şekil 6'da görüldüğü üzere yazarın eserlerinde amacına göre en çok kullandığı ileti türü \%51 oran ile kişisel gelişimi desteklemeye yönelik iletilerdir. $\mathrm{Bu}$ sonuç, iletiler üzerine yapılmış diğer çalışmalarla paralellik göstermektedir. Cesur (2015), Tekin (2018), Gülgönül (2014) gibi araştırmacılar tarafından yapılan çalışmalarda da kullanımı en fazla tespit edilen ileti kişisel gelişimi destekleyen iletilerdir.

Yazarın eserlerinde tespit edilen kişisel gelişimin desteklenmesine yönelik 394 iletiden en çok kullandığı ileti 38 kullanım sıklı̆̆ıyla "Mutlu olmak" iletisidir.

Yazarın bu alanda en sık kullandığı iletiler ve kullanım sıklıkları aşağıda tablo olarak verilmiştir.

Tablo 6. 1.alt problem ile ilgili kullanım sıkliğı en fazla olan 5 ileti

\begin{tabular}{lll}
\hline İleti Kodu & İleti Ad1 & F \\
\hline K38. & Mutlu olmak & 33 \\
K9. & Umutlu olmak & 18 \\
K13. & Takdir etmek & 18 \\
K2. & Yalan söylememek & 14 \\
K12. & Başarılı olmak & 14 \\
\hline
\end{tabular}


Yazarın eserlerinde fazlalık bakımından 2. sırada bulunan ileti türü 155 ileti ve \%20'lik oranla toplumsal gelişimi destekleyen eğitsel iletilerdir. Bu ileti türünde en çok kullandığı iletiler ve kullanım sıklığı ise şöyledir:

Tablo 7. 2. alt problem ile ilgili kullanım sıklı̆̆ı en fazla olan 5 ileti

\begin{tabular}{lll}
\hline İleti Kodu & İleti Adı & f \\
\hline T22. & Toplumun sosyal yaşamını tanımak & 23 \\
T1. & Anne babayı sevmek & 16 \\
T6. & Eğitim sorunlarını gidermek & 16 \\
T24. & Arkadaşlı̆̆a ve dostluğa önem vermek & 14 \\
T2. & Öğretmeni sevmek & 12 \\
\hline
\end{tabular}

Buradan hareketle yazarın, okurlarına toplumun sosyal yaşamını tanıtarak onları toplum yaşamına hazırlamayı amaç edindiği söylenebilir. Ayrıca yazarın hemen hemen her eserinde bir öğretmen kahraman bulunmaktadır. Kendisi de öğretmenlik eğitimi almış olan yazar, öğretmeni eserlerinde yol gösterici, bilge ve toplumu aydınlatan yönleriyle işlemiştir.

Yazarın eserlerinde sayı bakımından 3. sırada olan ileti türü 97 ileti sayısı ve \%13'lük oranla çevre bilincini destekleyen iletiler yer almaktadır. Yazar çevre konusuna çok duyarlıdır. Özellikle hayvan sevgisi, ağaç sevgisi, çevrenin özelliklerini tanımak, köy yaşamını tanımak gibi iletileri sıkça kullanmaktadır.

$\mathrm{Bu}$ ileti türünde en çok kullandığı iletiler ve kullanım sıklığı ise şöyledir:

Tablo 8. 3. alt problem ile ilgili kullanim sıkliğı en fazla olan 5 ileti

\begin{tabular}{lll}
\hline İleti Kodu & İleti Adı & f \\
\hline Ç1. & Hayvanları sevmek ve korumak & 32 \\
Ç3. & Mekânları tanımak & 18 \\
Ç5, & Köy yaşamını tanımak & 10 \\
Ç6. & Çevrenin özelliklerini tanımak & 10 \\
Ç4. & Doğa olaylarını tanımak & 9 \\
\hline
\end{tabular}

Yazarın eserinde sayı bakımından 4. Sırada yer alan ileti türü 73 ileti ve \%9 oranla evrensel düşüncenin gelişimini destekleyen iletilerdir. 
Tablo 9. 5. Alt Problem İle İlgili kullanım sıklı̆̆ı en fazla olan 5 ileti

\begin{tabular}{llcl}
\hline İleti Kodu & İleti Adi & F & \\
\hline E6. & Barışı savunmak & & 13 \\
E2. & Merhametli olmak & & 11 \\
E9. & Demokrasiyi savunmak & 8 & \\
E3. & Fedakâr olmak & 6 & \\
E4. & Hirsizlık yapmamak & 6 & \\
\hline
\end{tabular}

Tablo 9'ten hareketle yazarın okurlarına barış yanlısı olma davranışını kazandırmayı amaçladığı söylenebilir.

Yazarın eserlerinde 57 ileti sayısı ve $\% 7$ oran ile de ulusal bilincin gelişmesine yönelik iletiler bulunmaktadır. Bu iletilerin dağılımı ve kullanım sıklığı da şöyledir:

Tablo 10. 4. alt problem ile ilgili kullanım sıklı̆̆ı en fazla olan 5 ileti

\begin{tabular}{llll}
\hline İleti Kodu & İleti Adı & f \\
\hline U2. & Ulusal kültür ürünlerini tanımak & 16 & \multirow{2}{*}{13} \\
U5. & Ulusal duygular taşımak & & \\
U7. & Atatürk'ü sevmek & 7 & \\
U9. & Tarihi eserlere önem vermek & 5 & \\
U3. & Vatanı sevmek & 4 & \\
U1. & Ulusal benliğini korumak & 4 & \\
\hline
\end{tabular}

Bu ileti alanında yazar okurlarına millî kültür ürünlerini tanıtmayı, ulusal duyguları, vatan ve Atatürk sevgisi aşılamayı amaçlamıştır.

İbrahim Örs'ün eserlerinin genelinde şahıs kadrosunun içinde “Öğretmen” karakteri yer almaktadır. Öğretmen, eserde sorunların çözümünde yol gösteren, akıl danışılan kişidir. Eğitim sorunlarıyla başa çıkmaya çalışan, öğrencilerin eğitim hakkından geri kalmaması için mücadele gösteren rollere bürünür. Romanın karakterleri öğretmenlerini sever. Nadir de olsa satır aralarında kötü öğretmen tipine de yer verilmiştir.

İbrahim Örs'ün eserlerinin genelinde yer alan bir diğer şey ise "Hayvan kahraman" dır. Eserin kahramanı genellikle bir hayvan besler. Bu kimi zaman bir köpek, kimi zaman bir kedidir. Kahramanın yoldaşıdır. Bazen onun söylediklerini yaparak olayın gidişatında etkili olur. Yazar bu yolla okurlarına hayvan sevgisi aşılamak istemiştir.

İbrahim Örs eserlerinde yer olarak köy, kır gibi mekânları kullanır. Karadeniz, Gümüşhane, Trabzon yöresi en sık kullanılan mekânlardır. Bunda yazarın o yöreden olması da etkili olabilir. 


\section{Öneriler}

- Yapılan bu çalışmada İbrahim Örs'ün eserlerinin eğitsel ileti bakımından zengin ve çeşitliliğe sahip olduğu sonucuna ulaşılmıştır. Yazarın dilinin sade, anlatımının akıcı ve duru olması; eserlerin daha çok macera türünde olması ögrencilere okuma becerisi kazandırma konusunda etkili olacağı düşünülmektedir.

- Bu çalışmanın sonucunda elde edilen bulgular ve varılan sonuçların okuma tavsiyeleri konusunda eğitimcilere ve ebeveynlere yol gösterici olacağı düşünülmektedir.

- Kitap okurken neyin okunulacağını belirlemek için ya da ihtiyaca yönelik okuma planları için bu çalışma içerdiği bulgu ve sonuçlarla yardımcı olacaktır.

- İ̉brahim Örs ve eserleri üzerine daha önce hiçbir çalışmanın yapılmamış olmasından dolayı yazar üzerine yapılacak çalışmalarda faydalanılabilir. 


\title{
EXTENDED ABSTRACT
}

\section{Analysis of The Works of İbrahim Örs About Children in Terms of Educational Messages}

\author{
Serdar Derman-Murat Acele \\ Necmettin Erbakan University
}

Every book tries to convey a certain message to the reader. Messages that children get from the books they read influence their cognitive, emotional, moral and personal developments. For this reason, children's books are important in terms of the messages they contain. Through the identification and analysis of the educational messages that Ibrahim Örs'13 children's books, this study aims to determine aspects of children Ibrahim Örs attempts to develop with the messages he wanted to convey to children.

This study takes as its problematic the identificationand determining the purposes of of the educational messages in the children's books written by Ibrahim Örs, with the problem statement: “What are the educational messages in children's books written by İbrahim Örs and how are these messages conveyed to the reader?"

As part of the main problem statement, we have identified 5 sub problems, which are 1. What are the educational messages in Ibrahim Örs' work which support personal development? 2. What are the educational messages in Ibrahim Örs' work which support social development? 3. What are the educational messages in Ibrahim Örs' work which support the development of environmental awareness? 4 . What are the educational messages in Ibrahim Örs' work which support the development of national awareness? 5. What are the educational messages in Ibrahim Örs' work which support the development of universal thinking?

The 13 children's books written by Ibrahim Örs constitute the scope and the objects of analysis of this study, which aims to identify the educational messages and the goals of these messages. Since the book titled "Göl Çocukları" (Children of the Lake) was previously published under the title "Cambazlar Kralı" (The King of Acrobats) and since the content is the same, the version published as "Cambazlar Kralı" was not included in the analysis. 
This study, which aims to identify the educational messages in the children's book written by Ibrahim Örs is a qualitative and descriptive study. Five different categories and five codes for each category were created, focusing on the educational messages in all the books written by Ibrahim Örs. As the study required content scanning, the document analysis method was employed. In this study, which aims to identify the educational expressions in Ibrahim Örs' work, the documents were analysed using the descriptive content analysis method.

In the coding of the data acquired from Ibrahim Örs' work in the study, the coding method was "Coding based on the concepts taken from the data".

Categories were developed by reviewing the educational messages in $\mathrm{Ib}$ rahim Örs' work in terms of their similarities and common points. Getting assistance from field educational experts and experienced Turkish teachers, all codes were linked to respective categories.

Each message category was coded based on their initial letters, and the categories were numbered based on the initial letter as the first letter of the category they belong to.

The coding of the "Educational Messages According to Their Purposes" were determined as follows:

1. Educational messages supporting personal development were coded with the letter " $\mathrm{K}$ " (personal - kişisel in Turkish); 2. Educational messages supporting social development were coded with the letter " $\mathrm{T}$ " (social - toplumsal in Turkish); 3. Educational messages supporting the development of national thinking were coded with the letter " $U$ " (national - ulusal in Turkish); 4. Educational messages supporting the development of environmental awareness were coded with the letter "Ç" (environmental - çeore in Turkish); 5. Educational messages supporting the development of universal thinking were coded with the letter " $E$ " (universal - evrensel in Turkish).

After the analysis, the findings were presented in tables. The order of the books in tables and graphs followed the date of first publication, from the oldest to the newest.

In the works of the author, 394 messages were identified under the first sub problem category. The 394 messages found in this book make up 50,77\% of the total 776 messages found in all the books. This ratio indicates that the category in which the author gives his reader highest number of messages is 
the category of personal development. Of the 394 messages supporting personal development, the one with the highest frequency is the message of "being happy" (33), which is followed by the messages of "playing games" (19), "being hopeful" and "appreciation" (18) respectively. The sum of these four messages make up $22 \%$ of this message category.

In the works of the author, 155 messages were identified under the second sub problem category. The message with the highest frequency in this category is the message of "recognising the social life of the community" with 23 messages, which is followed with "solving educational problems" and "loving the parents with a frequency of 16 . The 155 messages identified in this category make up $19,97 \%$ of the total number of messages. With this ratio, this category comes in $2^{\text {nd }}$ place in terms of the number of messages.

97 messages were identified with regards to the $3^{\text {rd }}$ sub problem. In this educational message category, the message with the highest frequency was the message of "Loving and protecting animals" with 32 messages, followed by message of "Recognising Places" with 18 messages.

A total of 57 messages were identified with regards to the $4^{\text {th }}$ sub problem category. The highest number of messages in this category were the message of "Recognising National Cultural Products" with 16 messages, "Having Emotional Sentiments" with 13 messages, and "Loving Atatürk" with 7 messages.

73 messages were identified with regards to the $5^{\text {th }}$ sub problem category. The messages with the highest frequency in this category were "Defending Peace" with 13 messages, "Being Merciful" with 11 messages and "Defending Democracy" with 8 messages.

A total of 776 messages were identified in the 13 books of Ibrahim Örs that were analysed. Of these messages, 394 were messages supporting personal development, 155 supported social development, 97 supported environmental development, 57 supported the development of national thinking, and 73 supported the development of universal thinking.

\section{Kaynakça / References}

Akbayır, S. (2010). Çocuğum neyi okumalı (2. baskl).Ankara: Pegem Akademi. Aktaş, Ş. ve Gündüz, O. (2004). Yazılı ve sözlü anlatım-kompozisyon sanatı (5. baskl). Ankara: Akçă̆ Yayınları. 
Aytaş, G. ve Yalçın, A. (2003). Çocuk edebiyatı (2.baskı). Ankara: Akçağ Yayınları.

Berg, B. L., ve Lune, H. (2015). Sosyal bilimlerde nitel araştırma yöntemleri. Konya: Eğitim Yayınevi.

Cesur, E. (2015). Mavisel Yener"in çocuklara yönelik öykülerindeki eğitsel iletiler üzerine bir araştırma. Yayımlanmamış Yüksek Lisans Tezi, İstanbul Aydın Üniversitesi, İstanbul.

Çılgın, A. S. (2007). Çocuk edebiyatı. İstanbul: Morpa Kültür Yayınları.

Creswell, J. W. (2016). Research design: Qualitative, quantitative, and mixed methods approaches. (S.B. Demir, Çev. Ed.), Ankara: Eğiten Kitap Yayınları.

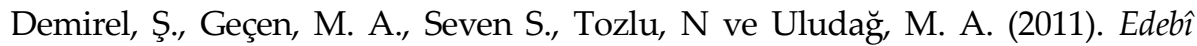
metinlerle çocuk edebiyatı. Ankara: Pegem Yayıncılık.

Dilidüzgün, S. (1996). Çă̆daş çocuk yazını (1.Baskı). İstanbul: Yapı Kredi Yayınları.

Genel, M. (2014). Almanya'ya giden ilk Türk işçi göçünün Türk basınındaki izdüşümü

"Sirkeci Garı'ndan Munchen Hauptbahnhof'a". Selçuk Üniversitesi İletişim Fakültesi Akademik Dergisi, 8(3), 301-338.

Güleryüz, H. (2006). Yaratıcı çocuk edebiyatı (3.Baskı).Ankara: Pegem A Yayıncılık

Gülgönül, B. (2014). Bilgin Adalı'nın hikâye ve romanlarında yer alan eğitsel iletiler.

Yayımlanmamış Yüksek Lisans Tezi, Dokuz Eylül Üniversitesi, İzmir.

Kıbrıs, İ.(2010). Yeni yüzyıl için çocuk edebiyatı. Ankara: Eylül Kitabevi.

Mayring, P. (2000). Nitel sosyal araştırmaya giriş.(Çevirenler: Adnan Gümüş, M. Sezai

Durgun). Adana: Baki Kitabevi.

Nas, R. (2002). Örneklerle çocuk edebiyatı(1.Baskı). Bursa: Ezgi Kitabevi Yayınları.

Oğuzkan, A.F. (2000). Yerli ve yabancı yazarlardan örneklerle çocuk edebiyatı (6.baskı).

Ankara: Anı Yayıncilik.

Örs, İ. (1981). Muhtarın yeğenleri (3.baskı). Ankara: Karacan Yayınları

Örs, İ.( 1975 ). Mücahitin oğlu ( 1. baskı ). İstanbul: Milliyet Yayınları

Örs, İ. ( 1980 ). Göl çocukları ( 1. baskı ). İstanbul Remzi Kitabevi

Örs, İ. (1980b). Çocuk cumhuriyeti. İstanbul: Milliyet Yayınları

Örs, İ. (1981). Onur çocuğu (2. baskı). Ankara: Karacan Yayınları

Örs, İ. (1982). Büyük tutku (1.Baskı).Karacan Yayınları: İstanbul

Örs, İ. (1982). Almanya öyküsü (2. baskl). İstanbul: Karacan Yayınları

Örs, İ. (1982).Yeşil mağara. İstanbul: Milliyet Yayınları

Örs, İ. (2011). Balıklkkoy (1. baskı). İstanbul: Şimşek Yayınları

Örs, İ. (2011). Fındık zamanı (1.baskı). İstanbul: Şimşek Yayınları

Örs, İ. (2018).Atıl'ın maceraları-1/Sınıftaki afacan (1.Baskı). İstanbul: Nemesis Kitap

Örs, İ. (2018).Atıl'm maceralart-1/Mavi bisiklet (1.Baskl). İstanbul: Nemesis Kitap

Örs, İ. (2018) Bütün öyküleri (1. baskı). İstanbul: Nemesis Kitap 
Özdemir, E. (2007). Yazınsal türler (6. Baskı). Ankara: Bilgi Yayınevi Sever, S. (2017). Çocuk ve edebiyat. İzmir: Tudem Yayınları.

Tekin, A. (2018). Aytül Akal"in çocuk kitaplarının eğitsel iletiler açısından incelenmesi. Yayımlanmamış Yüksek Lisans Tezi. Gaziantep Üniversitesi, Gaziantep. Ylldırım, A ve Şimşek H. (2011). Sosyal bilimlerde nitel araştırma yöntemleri(8. baskl). Ankara: Seçkin Yayınclik.

Yalçın, A. ve Aytaş, G. (2014). Çocuk edebiyatı (2.Baskı). Ankara: Akçağ Yayınları.

\section{Kaynakça Bilgisi / Citation Information}

Derman, S. ve Acele, M. (2020).İbrahim Örs'ün çocuklara yönelik eserlerinin eğitsel iletiler açısından incelenmesi.OPUS-Uluslararası Toplum Araştırmaları Dergisi, 15(25),xxx-x.DOI: 10.26466/opus.702195 